\title{
EVALUATION OF THE LAW RELATING TO MEDICAL NEGLIGENCE IN SRI LANKA
}

\author{
H. L. N. S. Chandrasiri ${ }^{1}$
}

University of Colombo, Faculty of Law, Centre for the Study of Human Rights ${ }^{1}$

\begin{abstract}
Reasonable competent and skilled medical practitioners owe a duty of care to their patients. Medical negligence and malpractice are expressions that are used in the medical community very often. It is hard to collect a handful of successful Sri Lankan case law documents that reached the Supreme Court. However, an exception exists from the landmark case of Priyani Soyza v. Rienzie Arseculerathe for the Recovery of Damages for the Death of a Person prior to enacting Act No.2 of 2019. This case law is just a tip of an iceberg. Many more merits have still been underreported. Prevailing tort liability of medical negligence in Sri Lanka is neither the best nor certain. The professionally skilled staff owe a huge debt of gratitude to their clients to perform a reasonable duty of care. However, when it comes to human health, the professional relationship becomes livelier and more sensitive. Negligence is a common terminology in any profession, occupation, business, or trade where a prudent person would not reasonably omit or commit, resulting in ultimate physical, mental, or economic loss. The growth of science and technology and free health policy in Sri Lanka have been taking an immense struggle through legislative, international conventions case laws, and eminent legal commentaries to fulfill the patient-oriented medical system. This paper aims to analyse and evaluate the ups and downs of the Sri Lankan legal system regarding medical negligence while comparatively introducing successful sources from other jurisdictions. Primary and secondary data collected were analysed using the qualitative research approach in this study. In this study, the qualitative research approach was used and data for analysis were gathered from both primary and secondary sources. In conclusion, admire the hypothesis and recommendations of the successful green pasture oasis used in consumer protection law, professional insurances, and non-fault redress for prevailing tort-based Medical Negligence.
\end{abstract}

KEYWORDS: Medical Negligence, Sri Lanka, Insurance, Consumer, Profession

Corresponding author: H. L. N. S. Chandrasiri, Email: nadeeshahl@yahoo.com 


\section{INTRODUCTION}

\section{Negligence in the general}

The modern law concept of Negligence lights up with the concept of 'love your neighbours' from the wording of Lord Atkin's 1932 case law of Donoghue v Stevenson [(1932) A.C.562]. Thus, with the merits of the Negligence, the interpretations from Palsgraf $v$ Long Island Railroad Corporation (248 N.Y. 339), Hay or Bourhill v Young [(1943) AC 92], Caparo v Dickman [(1990) UKHL 2], Hill $v$ Chief Constable of West Yorkshire [(1987)UKHL 12], and Osman v UK [(1998) ECHR 101] grow up with new vocabulary including foreseeability, proximity, fairness, justice, and reasonableness even in the absence of a contract.

So, the traditional definition of negligence brings up the idea of taking reasonable care to avoid acts or omissions that can reasonably foresee the damage to your neighbours and your ultimate consumer. Theoretically, the law used to satisfy duty, the breach of duty, damage, and causation with four elements to establish Negligence, according to the authority of Lochgelly Iron and Coal Co v McMullan [(1934) ACl, 25].

\section{Medical Negligence}

Medical Negligence is a special branch of Negligence. It leads to complaints or litigation about an inadequate standard of medical care given to a patient. Bolam [(1957) 1 WLR 583] test is like an indicator that looks for four elements in the failure to perform the owed duty. Thus, the author is advising the reader to look for a reasonable degree of skill and care in diagnosing and treating a patient causing damage in some bodily, mental, or financial disability in most countries. There are civil societies and non-profit organizations that provide defence and insurance to their medical professional members. Civil medical negligence and Criminal medical negligence are the two types generally followed by every jurisdiction worldwide. Medical negligence litigations are very serious and need a deep concentration with medical and legal technological and terminology practicality. In reality, there are few alleged medical negligence cases reported. Some cases have gone up to courts, and most of them have settled outside. So, it is hard to find a simple or clear-cut medical negligence litigation that awards compensation. Often the lawyers have to collect a great deal of information and wisely analyse all circumstances. Ankur Arora Murder Case (Tatari. S, 2013) is a brilliant movie directed by Mr. Suhail Tatari, which brings to the limelight a well-known medical professional's act or omission to perform an owed duty that caused medical negligence. It is a story of an innocent boy who could not survive due to negligent pre-operational care after an appendectomy. However, this boy's mother is capable enough to expose the fatal flaws in the medical profession throughout the film.

\section{METHODOLOGY}

Research information is valuable for gathering knowledge and sharing knowledge in an especially arranged systematic methodology, hoping for a scientifically worthy outcome. So, scientific outcomes favour cumulative common features through ontology and epistemology of the paradigm. Thus, the present study attempted to evaluate the existing laws and legislations analytically. Comparing Sri Lankan legislation with other relevant, effective, good governance standards is therefore required to be done by allowing access to the human rights of those other countries. In doing so, the researcher followed a qualitative research methodology.

The researcher was able to gather primary and secondary data with the aid of the black letter technique. Authentic books, journal articles, conference proceedings, and other online sources are secondary. The desk research review is the commonest elaborative method available those days with Covid pandemic and health restrictions. Special attention has been given to the comparative analysis pathway to evaluate Sri Lankan and successful international jurisdictions. Next, with empirical research observations, the study clarifies the difficulties in establishing medical negligence laws and practical ways of introducing country-oriented own inherited norms along with human rights internationally accepted. 


\section{RESULTS}

\section{Civil medical Negligence}

Sometimes civil medical Negligence is known as malpractice (Chandrasiri. N, 1999). In general terms, all patients have the right to expect satisfactory, standard medical care, treatment, management from admission and aftercare. Everyone completes their duty with self-confidence and guarantees success with the academic and clinical practices they gain from training and experiences. But sometimes, biological factors play an important role in producing an unpredictable outcome. However, the patient is entitled to receive financial compensation if they can prove the harm or loss resulting from the commitment or inability to perform the medical professional's reasonable standard of medical care. The rationale of awarding damages by a civil court is to renew the financial loss suffered. Every Sri Lankan civil court (district court) can award compensation for physical or mental damages caused by a breach of owed care by a medical practitioner. The most important question that courts ask is whether the respondent doctor would have done or omitted doing what an average doctor of the same seniority and experience would have done in an identical circumstance regarding the patient's condition and the location of the examination and treatment conducted. Sometimes, there are crystal clear situations where "things or facts speak for themselves" (res ipsa loquitor), and that situation shifts the burden to prove to a medical practitioner. In some situations, the civil courts have to adopt the procedure to find out from peers about opinions regarding medical issues. The experts consider the details of the case to check whether a reputable and acceptable medical practice performed that act.

A medical malpractice insurance policy is available in many countries to safeguard patients against doctors who breached their professional responsibilities. So, under civil cases, even a seriously harmed patient cannot get any certain compensation in this tort system if the matter fails. The general sense is that the legal process is very slow, takes several years, and involves a lot of expenses. Therefore, only a few people will bear the time and money consumption at the medical negligence litigation. To overcome the unfairness in civil litigation, most countries like New Zealand, Finland, Sweden, and Norway introduced the no-fault system to their victims seeking compensation. This system tests not the medical practitioner's Negligence but the patient-centered safety. Patients who choose nofault insurance get reimbursed by their companies, workers, and the state.

A no-fault system is like a strict liability that does not need proof of damage caused. The patient's only thing to prove is that the medical professional breached the owed duty to care to receive compensation for the damages. As there are two sides to one coin, the only disadvantage of the no-fault system is that this system can pay only a small quantum. A no-fault system is a method that is for all or nothing. Accordingly, the burden of proof has to achieve at least fifty-one percentage to win the claim.

On the other hand, if the result is forty-nine percentage, then the patient gets nothing. He/She loses everything available in the case matter. So, this frustrates the severely affected patient if they do not file a tort suit at civil courts against the medical practitioner who breaches the owed duty of care within his authorised profession. Litigations are extremely expensive, and they take a lot of time. Usually, rich people and poor people who gain legal aid can fight for this. Another sad situation is that it is extremely difficult to get a medical opinion in favour of a patient who suffers the breach of Medical Negligence. Expert views and secondary opinions do not help much in these cases as most professionals usually refrain from voicing their thoughts against their peers in their respective professions.

\section{Duty of care}

Under the definition of medical Negligence (Knight. B, 1992), a medical practitioner should be under obligation to his/her patient from the beginning of the consultation and admission of the patient. It is unnecessary to prove the relationship between the medical professionals and the patients as it implies with the commencement of the treatment. The relationship between those medical professionals and their patients is strong (Alwis. L. B. L, 2011). They promise and pledge to do their best in the interest of the patient 
always. The government hospitals of Sri Lanka are free of charge. When a patient admits to a hospital, the nursing staff assign them to a ward, and the obligation towards the patient begins thereon. Then the patient is assigned to be under the supervision of a senior nursing officer in charge and respective authorized doctors (Jayawardena. H, 1994). All payments include from the government's revenue, derived from taxes paid by citizens. The same process is in private hospitals from the onset of the consultation relationship between the medical professional and the patient. However, the patients have to bear the costs of the consultation fees, admission fees, treatment, and medical care themselves. This is a pathetic situation which is far beyong what medical practitioners are promised and pledged.

\section{Skill and care}

The next important issue is, whether a reasonale degree of skill and care is indicated on the part of the medical professionals. There is no guarantee that a hundred percent success can be achieved in all treatments, operations, or in anything medical professionals do. But things done or omitted can worsen a patient's condition, which can be tantamount to professional neglegance.

\section{The standard of care and skill}

Health care providers do not have to provide the greatest level of care or expertise under the current standards. Also, it is not enough when there has been a minimal degree of skill than the general professionals expect. But things done or omitted can worsen a patient's condition, which can be tantamount to professional neglegance.

The standard of care required is not the exceptionally brilliant character of a medical professional. Being a physician, a surgeon, or a nurse cannot guarantee absolute care and safety. So, those medical professionals are not liable when something unexpected happens. Negligence is not a mere slip or a mistake. However, the standard necessary for the law differs according to the given circumstances. For example, a severely injured person with severe bleeding may seek treatment from a rural hospital that lacks the required facilities to treat such a person due to heavy traffic. Even though the medical staff and doctors start treatment with their maximum efforts, the patient may die due to the lack of required facilities in that hospital. It is not medical negligence.

On the other hand, even when a newly qualified physician or a surgeon undertakes a duty, the standard of competent skill and care expected from such a specialist may not reach similar to an experienced professor in the relevant field.

The standard of care can differ according to the emergency and the priority of saving the patient's life. The general practitioner is not a qualified professor in the field expected to exercise under the reasonable standard of care and skill. But medical professionals do not excuse themselves when careless as a layperson.

\section{Causation and damage}

A patient is awarded compensation for the breach of professional medical Negligence only at the evidence of damages. Damages have to be by the negligence of a medical professional's owed duty, but not by the consequences. The patient must prove that damage could not have occurred but for the medical professional's negligence.

\section{Sri Lankan judges' quality of the standard view}

Competent medical practitioners always check the quality of the medical practices in the field based on the evidence. So, the most relevant and only reported case in Sri Lanka is none other than the Arsecularatne vs. Soyza case. In 1994, the District Court of Colombo called for a neurologist, neurosurgeon, and two Professors of Paediatrics to obtain secondary medical evidence. According to the case facts, the parents of the baby Suhani Arsecularatne had consulted the defendant, Prof Priyani Soysa, a consultant paediatrist at Navaloka private hospital. Even one month after treating the patient, there were no signs of recovery or healing other than the deterioration of her condition. Eventually, the child had died. The misdiagnosis of Priyani Soysa, according to the trial court, may have been averted if the respondent Paediatric had paid more attention to her patient.

At the Appeal Court, judges found the medical practitioner negligent in taking a proper patient history. Also, she had failed to record the history taken and had 
prescribed a simple investigation called CT scan for the baby patient. The trial indicated that the diagnosis of rheumatic chorea without recording and considering inconsistent symptoms with such diagnosis was the mistake. However, in practice, shortcomings are accentuated because physicians do not document clinical observations. The courts need every reasonable evidence of everything that the medical practitioner has done to make a reasonable decision according to the circumstance. In the case under discussion, the court could conclude if the bedhead ticket of the baby Suhani had reasonable notes. Generally, the medical practitioner records the patient's important positive and negative features and not everything in the bedhead ticket. However, the Court of Appeal declared that "a doctor who considers too important not to condescend to write history on a bedhead ticket or make referral notes herself cannot be expected to have treated the child or parents with care and respect, nor given herself sufficient time to investigate and reconsider her initial diagnosis of rheumatic chorea." The trial judge's view was that "Negligence is a feature of the present and past if admitted in law. A doctor shall treat the child to the best of the practitioner's ability, irrespective of the future outcome.

One cannot use an extended peep into the future with the knowledge of medical science as it exists in the present as a weapon to ward off the evil effects of our present or past action." Recovery of Damages for the Death of a Person Act (Recovery of damages, No.2 of 2019) to determine parties on the death and loss of love, affection, care, and companionship has become the latest reference. Thus, the next-of-kin with a wide range of variety individually or jointly as a parent, child, sibling, grandparent, a guardian can appear before the courts on behalf of the dead person of an action for damages caused by a medical professional's breach of an owed duty by a wrongful act, omission, negligence, or commission against a reasonable person. Lack of case laws in negligent medical law recalls for more reforms. There is a need for a gradual fulfillment to Acquilian Action to recover damages other than patrimonial loss or physical hurts. Earlier, there was no compensation for mental distress, physical injury, loss of care, and companionship. The Recovery of Damages for the Death of a person Act No. 2 of 2019 has introduced several legal qualities overlooked since the landmark case of Prof. Priyani De Soyza versus Arsecularatne ruling, handed down in 2018.

\section{Duty of medical practitioner and rights of patients}

Generally, Americans are used to practicing the patientoriented standard. According to Canterbury v Spence (464 F.2d 772), the patient has the right to inform, and medical professionals are under a duty to disclose all the information. But the final selection is with the patient. The British form a medical professionaloriented method. According to Sideway, the doctor has the selection of what to disclose and not to the patient. The medical practitioner should always be aware of recent developments as common knowledge, including accepted methods in history taking, clinical examinations, investigations, diagnosis, treatments, prevention, therapies, and care after treatments. In some situations, a junior works for long hours, and tiredness or being untrained can lead to losing skill in making judgments. So, there can be situations where these fatigues or lack of knowledge may lead a person to neglect a necessary step or to follow an incorrect procedure, and it may lead to the breach of one's owed duty as a medical practitioner making him/her liable to pay medical negligence compensation awards. In practice, there were many incidents that an untrained blood bank medical officer's incompatible blood group caused the death of a patient. Also, doctors, nurses, pharmacists, and other relevant medical professionals should consider the warnings, circulars, quality failures, side effects sent through health services and regulatory committees regarding drugs. There is no excuse for being in a rural area or a village. Reading a recognised journal like Ceylon Medical Journal, British Medical Journal, and Lancet is very helpful to gain new knowledge. As a practice, a medical professional enters all information in bedhead ticket from the arrival of a patient for diagnosis, clinical findings, investigations and even consequences and follow-ups after discharge. But most of the busy senior doctors in Sri Lanka are used to writing a minimum or they ask their juniors to write in detail in the bedhead ticket.

The duty is to inform complete information to the patients about the risk of a proposed treatment while giving detailed benefits of the treatments. The patient is 
entitled to know the situation even when he/she is anaesthetised. Even though the medical professions do not need to admit Negligence, patients have a right to know everything to the fullest disclosure. Particularly, the patient should know the committed and omitted things even when things go wrong. When competent medical professionals are brave enough to follow a procedure that has not been used yet for the first time without approval through clinical trials or science to save lives, that is not considered an accepted practice of medicine. So, in these circumstances, the patient has a right to be well informed of the procedure of the experiment.

However, the old fashion has to tail off and act as minority practice when new technology goes better than the older methods. So, the patient has the right to ask for newly accepted technology in their medical care procedure. Another interesting fact is that, in Sri Lanka, proving medical Negligence against medical professionals is a stranger subject matter than in other countries. Common people cannot compel doctors or other medical professionals to provide their medical records or to those of their relatives. Even the law has not yet considered this area much. Although patients have a right to get a copy of their medical records, even if they are the property of doctors and hospitals, they must pay a small fee to do so. Sections 33 to 35 of the Supreme Court Act, 1981 of England (Supreme Court Act, 1981) provide the High Court authority to order, possess, and disclose all documents before filing a case.

A complaint was made on medical negligence liability to doctor and the hospital consider according to common law authority in McCormack v Redpath Brown and Company and another (Lancet, 1961:736.). But the final declaration was that the hospital needed to pay damages considering that the young and careful doctor had done his best in the circumstances even though he had lacked sleep and had been tired working for thirty hours. That is a good example that suits Sri Lankan situations with understaffed status and lack of facilities in unprivileged government and private hospitals. Sri Lankans followed English or other jurisdictional cases blindly, expecting to perform beyond available resources without thinking about the real condition and standard of care in those countries.

\section{Criminal medical liability}

The burden of proof that expects in criminal offenses is beyond a reasonable doubt. When pursuing a criminal medical negligence case, one must show that the level of carelessness involved warrants criminal prosecution. In civil medical Negligence, a patient who suffers can make a complaint against a medical professional with the intention of financial compensation, which is the most famous type in most jurisdictions. Punishments as punitive compensation awards to the alleged criminal medical negligence. Required men's rea is an amount of deliberate wicked, reckless, rash, or scant disregard towards their patient's life and safety. Generally, criminal medical Negligence in Sri Lanka before the magistrate court or the high court in litigation. Sometimes this kind of criminal wrong can be considered much more serious than Negligence at judgments. There is no malice or pre-mediation to destroy the patient's life, and the direct-action situation is different from murder. But the severe carelessness or lack of forethought can be considered as culpable homicide not amounting to murder according to Sri Lankan Penal Code and manslaughter in the United Kingdom. According to section 328 of the Sri Lankan Penal Code, a medical professional is liable for a criminally negligent act of rashness causing patient hurt. The punishment is a maximum of six-month imprisonment and a fine. Section 329 is for grievous hurt caused by the negligent act with the award of twoyear imprisonment and a fine. Finally, if the negligent act causes death, the courts can give a five-year sentence of imprisonment and a fine. Actually, in practice, there have been a very limited number of criminal medical negligence charges for the breach of owed duty by medical practitioners in jurisdictions worldwide, including Sri Lanka. Most probably, the reason is that states that have the power are reluctant to prosecute the noble people in the medical profession. But someday, states will prosecute medical professionals for their breach of owed duty for the commitment of Negligence, like damage caused due to the influence of drugs or alcohol or caused during a trade union action by failing to attend an emergency service. Civil responsibilities can ask to have immunity form trade unions. But, considering the patient's best 
interest at the circumstance criminal commitment looks in different spectacles.

\section{DISCUSSION}

\section{Medical professional insurance}

A typical insurance policy responds for bodily harm or property damage, and other forms of insurance cover employers, product liability, and any other general circumstances only. But medical professions can give rise to legal claims under the name of medical Negligence. But, authorities are reluctant to perform without any specific clause in those general policies in insurances. Under professional liability insurance, special policies like error, omission, or negligent act committed in the insured's medical professional duty based on circumstances are obliged to cover claims made during the policy period. The majority of American doctors, dentists, psychologists, pharmacists, optometrists, nurses, and physical therapists require consider this type of medical insurance for their professional careers. Depending upon the location and nature of the medical practice, insurance differs. Sometimes federal (USA) government made the insurance against medical negligence liability to protect the medical employees. Generally, medical professional insurance coverage seeks to protect medical professionals and the business surrounding too. All the expenses in medical Negligence litigation, including attorneys' fees, court costs, arbitration costs, settlement costs, compensation, and medical damages, are usually considered under indemnity covering. Medical professional insurances do not cover criminal acts, sexual misconduct, and misbehaviours. As a patient-oriented country, the USA always intended enhanced patient safety and non-judicial compensation by replacing tort liability.

\section{No-fault system}

The no-fault system is a new successful area introduced at the failure of civil and criminal medical Negligence practice in Sweden, Finland, Norway, and New Zealand. It does is not seek the doctor's Negligence at a breach of owed duty but always pays attention to the patient's need. Even though no-fault is a supplement with advantages, there are few regrets in this system too. The main disadvantage is the difficulty in identifying a qualified subjective area for compensation. The no-fault system is unfair for the patients who suffer serious medical Negligence as the compensation award is minimal and hardly pays large monetary amounts. Funding comes from the government, local council, and physicians. The basic steps to a no-fault system are so flexible. The victim patient makes an application to get compensation for medical negligence (malpractice). Then, a notification made by an expert panel to the physician has to give a written report about damages and procedures. Next, during the primary investigation, the eligibility of the application and medical report has to be determined. If the patient is supposed not to appear before the court, the panel has to interview the physician. The panel also can call for witnesses when necessary. The no-fault system does not intend to replace the court system. Within six months, payment for medical negligence compensation for violating a duty of care is made.

\section{Consumer Protection Act}

Magna Carta is the first charter that took the attention of the consumer. To protect the consumers within the wider business network, in 1986, the new Bill of 2019 (Consumer Protection Bill, 2019) replaced the exciting Act of Consumer Protection in India. The consumer disputes redressal forums are the statutorily established courts especially to hear consumer litigations. Section 7 of 2019 ( $2 d$ of old Act) identifies a person who avails a service for a consideration known as a consumer. At the same time, the deficiency of service leads to an injury to the consumer by any act of Negligence or omission or commission defined under section 11 of the new Act ( $2 \mathrm{~g}$ of old Act). The multiplier is a successful compensation calculating method. During the 90s, Mrs. Auradha Saha visited her hometown Kolkata, India. On the journey, she died due to an overdose of a wrong drug prescription by a negligent doctor who treated her skin allergy. Her husband, doctor Kunal Saha initiated the legal battle against the negligent actions of medical professionals that led to the death caused by a breach of an owed duty. Mr. Kunal Saha has relentlessly fought for fifteen years to establish justice for innocent patients like her wife. On $7^{\text {th }}$ August 2009, the Honest Supreme Court of India held four Kalkata based doctors and AMRI Hospital of Kalkata guilty for the death of Mrs. Auradha Saha in a historic 
judgment. The highest consumer court of the Indian National Consumer Disputes Redressal Commission (NCDRC) made the award for late Anuradha. Until now, this was the largest sum of money ever paid out in India. Awarded compensation is 1.7 crore of Indian Rupees on October $21^{\text {st }}$, 2011. Indian society is more active, and many organisations and societies have risen like 'People for Better Treatment' (PBT, 2014) to bring safety towards the victims of medical Negligence. However, the Indian Consumer Protection Act's provisions usually work with the government health institutions, excluding where all services are delivered free of charge. Free of charge services are reluctant to apply under Consumer Protection Act. Even in Sri Lanka, many people keep dying every day due to some breach of medical negligence owed by a medical professional. Sarla Verma and Nizam institution cases are some successful compensation awarded cases. Susamma, Trilok Chandra, and Charlies are the best examples where the development of law looked forward to considering consumer protection with a nofault compensation method.

In 2003, Sri Lankan law introduced the Consumer Affairs Authority No.9 with the hope of alleviating the weaknesses and limitations with the prevailing legislation by replacing the Consumer Protection Act 1979. As stated in the preamble, it aims to provide better protection for consumers through regulating trade and services against unfair practices. Reiteration of some words occurs in the Consumer Protection Act of India and Sri Lanka (Consumer Affairs Authority No.9 of 2003). For example, section 75 of the Sri Lankan Consumer Affairs Authority Act 2003 defines consumers and services the same way as in the Indian Consumer Protection Act sections 7 and 11. Definitions of consumer and service, in particular, are well-aligned. So, it is a "green light" to get used to consumer protection at medical negligence litigations from Indian statutes and common law.

\section{CONCLUSIONS}

Sri Lanka can adopt selected comparative methods to enhance patient safety to replace civil (tort) liability. Medical professional insurance method can be a good indemnity to protect the consumer (patient). Government-funded (full or half) for government hospital medical staffs or individual funded (medical professional) insurance against medical Negligence only arising for the provision. The government can make this a mandatory policy, as in some states in the USA. In reality, the prevailing tort liability of medical negligence compensation in Sri Lanka is neither certain nor punctual, nor fair. Non-judicial compensation appreciates no-fault compensation systems and Consumer Protection Acts. The no-fault system does not need any evidence of damage caused by Medical Negligence. At the same time, the Consumer Protection Act has to go through with statutory provisions to define consumer services and deficiencies to win the case.

No-fault system medical professionals come forward with their patients to improve the whole network in the medical system. A no-fault system is a flexible compensation award for the settlement of claims within six months. In the Consumer Protection Act, being a consumer has more rights than being a layman. Even though the no-fault system has been in place for almost twenty-five years in some of the world's most developed humanitarian nations, the ultimate award is a tiny amount of compensation. It is an 'all or nothing' procedure that frustrates the patient at times (consumer). A patient, when considered as a consumer, has more rights with medical negligence compensation than otherwise. However, professional medical insurance, no-fault system, and Consumer Protection Act will be better helpers to fill the gap when compared with other jurisdictional methods for medical negligence compensation. The people of Sri Lanka have to be more vigilant and enthusiastic about judicial activism on medical negligence compensation. There are a lot of Suhani Arsecularatnes, Anuradha Sahas dying every day, emphasising the need to enhance consumer (patient) safety with assured compensation for medical negligence. In this context, it recommends analyzing the merits of prevailing medical law and evaluating the protection available to the patient as a consumer through professional medical indemnity insured without any evidence of damages. The modern law concept of Negligence lights up with the concept of 'love your neighbours' from the wording of Lord Atkin's. 


\section{REFERENCES}

Alwis. L. B. L.(2011). Medical Ethics, Law and Psychiatry 1st ed. p. 182.

Ankur Arora Murder Case, (2013). A film directed by Suhail Tatari. Available at https://en.wikipedia.org/wiki/Ankur_Arora_Murder_C ase.

Bolam v Friern Hospital Management Committee (1957). 1 WLR 583.

Bourhill v Young (1943). AC 92.

Canterbury v. Spence (464 F.2d 772).

Caparo Industries plc v Dickman (1990). UKHL 2.

Chandrasiri. N. (1999). Textbook of Clinical Forensic Medicine and Forensic Pathology, 1st ed., (Upuli offset, Galle, pp. 16-20.

Donoghue v Stevenson (1932) A.C. 562.

Hill v Chief Constable of West Yorkshire (1987). UKHL 12.

Jayawardena. H (1994). Error in diagnosis and Negligence, Sunday Observer, 23rd of January,

Knight. B. Legal (1992). Aspects of Medical Practice, 5th ed., Churchill Livingstone, p. 67.

Lochgelly Iron and Coal Co. v. McMullan (1934). ACl, 25 .

McCormank v Redpath Brown and Company and another (1961). The Times, 24 March, 3C. L 500, Lancet, I, p.736.

Medical and Dental Defence Union of Scotland Ltd https://www.mddus.com/.

Medical Defence Union https://www.themdu.com/.

Medical Protection Society Ltd available at https://www.medicalprotection.org/.
Osman v. UK (23452/94) (1998). ECHR 101.

Palsgraf v. Long Island R. Co. - 248 N.Y. 339.

People for Better Treatment available at http://pbtindia.com/.

Supreme Court Act 1981 is available at http://www.legislation.gov.uk/ukpga/1981/54/pdfs/uk pga_19810054_en.pdf.

The national portal of India available at https://www.india.gov.in/consumer-protection-act. Accessed. 